\title{
The parable of the Feast (Lk 14:16b-23): Breaking down boundaries and discerning a theological-spatial justice agenda
}

\begin{tabular}{|c|c|}
\hline $\begin{array}{l}\text { Authors: } \\
\text { Ernest Van Eck } \\
\text { Wayne Renkin } \\
\text { Ezekiel Ntakir }\end{array}$ & $\begin{array}{l}1^{1} \\
2^{2} \\
\text { utimana }\end{array}$ \\
\hline \multicolumn{2}{|c|}{$\begin{array}{l}\text { Affiliations: } \\
\text { 'Department of New } \\
\text { Testament Studies Faculty of } \\
\text { Theology, University of } \\
\text { Pretoria, South Africa }\end{array}$} \\
\hline \multicolumn{2}{|c|}{$\begin{array}{l}{ }^{2} \text { Centre for Contextual Ministry, } \\
\text { Faculty of Theology, University } \\
\text { of Pretoria, South Africa }\end{array}$} \\
\hline \multicolumn{2}{|c|}{$\begin{array}{l}\text { Project leader: E. van Eck } \\
\text { Project number: } 2400030 \\
\text { Project leader: S.F. de Beer } \\
\text { Project number: } 86233689\end{array}$} \\
\hline \multicolumn{2}{|c|}{$\begin{array}{l}\text { Description } \\
\text { This research is part of two } \\
\text { different research projects. It is } \\
\text { part of the project, 'Socio- } \\
\text { Cultural Readings', directed by } \\
\text { Prof. Dr Ernest van Eck, } \\
\text { Department of New Testament } \\
\text { Studies, Faculty of Theology, } \\
\text { University of Pretoria and part } \\
\text { of the research project, 'Spatial } \\
\text { Justice/Spirituality and Health', } \\
\text { directed by Dr Stephan de Beer, } \\
\text { Director of the Centre for } \\
\text { Contextual Ministry and } \\
\text { member of the Department of } \\
\text { Practical Theology, Faculty of } \\
\text { Theology, University of Pretoria }\end{array}$} \\
\hline \multicolumn{2}{|c|}{$\begin{array}{l}\text { Corresponding author: } \\
\text { Ernest Van Eck, } \\
\text { ernest.vaneck@up.ac.za }\end{array}$} \\
\hline \multicolumn{2}{|c|}{$\begin{array}{l}\text { Received: } 30 \text { May } 2016 \\
\text { Accepted: } 11 \text { Aug. } 2016 \\
\text { Published: } 31 \text { Oct. } 2016\end{array}$} \\
\hline \multicolumn{2}{|l|}{ Read online: } \\
\hline 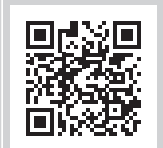 & $\begin{array}{l}\text { Scan this QR } \\
\text { code with your } \\
\text { smart phone or } \\
\text { mobile device } \\
\text { to read online. }\end{array}$ \\
\hline
\end{tabular}

The parable of the Feast (Lk 14:16b-23) is perhaps the example par excellence in the New Testament that addresses spatial justice and reconciliation. In the parable, Jesus advocates for the eradication of all boundaries linked to the social-economic status of the marginalised. The parable argues, from a social justice perspective, that there is no such thing as privileged space; priviliged space, on the contrary, builds boundaries. The reading of the parable presented critically engages with real-life experiences of marginalised people living on the periphery of the city and the boundaries that are created by megachurches in their close surroundings.

\section{Introduction}

Walking through the streets of Pretoria, or driving from one end to the other, you are confronted with the stark contrasted realities in which people find themselves. You can move past the seat of power of the Republic of South Africa (Union Buildings) and at the same time be confronted by the extreme poverty of homeless individuals occupying the sidewalks. Standing at the Hatherley dumpsite, in Mamelodi East, extreme opposites can be noted: big, expensive machinery bringing in waste from the city whilst poor, vulnerable people dig through it to seek survival.

This can be translated into the age-old theodicy question: 'Why does God allow bad things to happen'? Rephrasing the question into a more contemporary one: 'In a country as South Africa, with our inclusive constitution, how can this be happening?' How can this be allowed where almost $80 \%$ of the country's population define themselves as Christian (Census 2011)? Harvey (2012) asks the question of what:

are we to make of the immense concentrations of wealth, privilege, and consumerism in almost all the cities of the world in the midst of what even the United Nations depicts as an exploding 'planet of slums'? (p. 4)

There exists a tension of extreme wealth and extreme poverty. This tension creates boundaries which define access to housing, education, medical care and right to the city.

What type of city we want to live in is intertwined with the 'kind of people we want to be', the 'kind of social relations we seek' and 'what style of life we desire' (Harvey 2012:4). Do we want to live in a society that segregates the haves and the have-nots? Do we want to perpetuate the apartheid city to move the poor to the outskirts, the periphery of the city, without adequate access to services, and build the rich better, more secure, more exclusive environments? Do we let wealth dictate who has right to the city or do we consider the right to the city means that all can participate in a reinvention of the city for the common good (Harvey 2012:4)?

In this article, we will explore two contesting spaces: the Christian Revival Church (CRC) and the Hatherley dumpsite. These two spaces are in walking distance from each other. The rational for choosing the above-mentioned spaces is based on two levels. Firstly, because it was part of the discussions during the Spatial Justice Conference (see below) and, secondly, theological reasoning. CRC is a megachurch with immense wealth and Hatherley is a landfill site where people live from the city's waste. Hatherley exposes the 'poverty of church' and the 'impotency of public policy and city planning' (De Beer 2014a:7); it exposes the segregation in South Africa; it exposes the disregard for human life.

How to cite this article: Van Eck, E., Renkin, W. \& Ntakirutimana, E, 2016 'The parable of the Feast (Lk 14:16b-23): Breaking down boundaries and discerning a theological-spatial justice agenda', HTS Teologiese Studies/Theological Studies 72(1), a3512. http://dx.doi. org/10.4102/hts.v72i1.3512

Copyright: @ 2016. The Authors. Licensee: AOSIS. This work is licensed under the Creative Commons Attribution License.

Note: This article is part of the Special Collection titled 'Spatial Justice and Reconciliation', sub-edited by Stephan de Beer, of the Department of Practical Theology and the Centre for Contextual Ministry, University of Pretoria. 
This article will also explore the pre-industrial city of Luke $14: 16 b-23$ and how it relates to the modern city. The parable will be interpreted in its socio-cultural, political, economic and religious context. The boundaries that are created by honour, reciprocity and physical walls in the parable will be explored. The parable will be used to interpret the boundaries that exist between the dumpsite and the church.

\section{Moving between (physical) boundary lines}

Boundaries are used for different reasons. It can be used to indicate physical boundaries such as walls or boarders between countries. Boundaries in an abstract sense can help people navigate in relating to other people. Boundaries have the ability not only to protect but also to divide and marginalise people. The apartheid city used boundaries to segregate people. In modern-day cities (as well as in the preindustrial city), boundaries were used as a clear indication of where people are allowed to be based on their social or financial standing. Is there a boundary that separates Hatherley dumpsite and the CRC from one another? Or is there complementary interaction?

Cities interact complementary and more intensively when the one supplies the demand of the other and vice versa (Soja 1971:3). The interaction of the CRC and the Hatherley dumpsite (Mamelodi East) is not so much complementary. One creates waste and the other lives in it. The first has tremendous privilege and wealth, whilst the second tries to survive amongst the discarded, leftover waste of the first. What do we make of these discrepancies? It is easy to accuse the ruling party of South Africa that they only seek the interest of a few, whilst churches in our midst are doing the same.

\section{Spatial Justice Conference}

On 21-22 September 2015, a conference on spatial justice was hosted by the Unit for Social Cohesion and Reconciliation located in the Centre for Contextual Ministry, University of Pretoria. The conference was held in conjunction with the Religious Cluster of the Ubuntu Research Project which involves different key role players. The theme of this conference was prompted by a 2-year earlier conference in 2013 with the theme Rainbow: premise or promise? Consultation on social cohesion and reconciliation. It was also hosted by the Unit for Social Cohesion and Reconciliation. During the 2013 conference, it became clear that there was a need to reflect on theology and space, as well as to discern a theological spatial agenda.

The 2015 conference took place on the Mamelodi campus of the University of Pretoria. Part of the programme was an immersion exercise. One cannot be truly immersed in any place in just 2 days, but the aim of the immersion exercise was to become aware of the contested spaces that exist in the east of Pretoria. This was done by means of a few site visits. Two of the sites that the conference visited were the Hatherley dumpsite and the CRC, Pretoria.
In this part of the article, we will discuss various encounters at the two sites. We had encounters with the two sites not only as conference attendees, but we also visited the sites after the conference to gain a better understanding of these spaces.

\section{Megachurches}

In traditional Protestant churches, a church with more than 2000 regular attendees is defined as a megachurch. Some scholars suggest that churches with more than 10000 regular attendees are classified as 'gigachurches' (Maddox 2012:147). ${ }^{1}$

Megachurches are mostly regarded as an American phenomenon, but we find more and more megachurches in South Africa, such as the CRC. It is a global phenomenon, of which Maddox (2012) lists a few:

Rio de Janeiro's Universal Church of the Kingdom of God seats 12 000; the Embassy of the Blessed Kingdom of God for All Nations in Kiev claims 20000 members; Australia's largest, Hillsong, passed 20000 in 2008; Singapore's New Creation Church claims 22000 and its City Harvest 23 000. America's largest, Lakewood, in Houston, Texas, at 47 000, is dwarfed by the Redeemed Church of God in Lagos, which claims 500000 at its monthly Holy Ghost services, and Seoul's Yoido Full Gospel Church is estimated at 830000 and growing. Five of the world's 10 largest churches are in South Korea. (pp. 147-148)

\section{Encounters at Christian Revival Church, Pretoria}

The CRC is situated at the corner of Lynnwood and Solomon Mahlangu Drive, Pretoria East. The church is situated a few kilometres from Mamelodi and in almost walking distance from Hatherley. Next to the church are large shopping centres, and also Silver Lakes Estate. Silver Lakes Estate's website describes that entering the estate 'you will feel like royalty stepping into another world' ${ }^{2}$

Entering the premises of the church, it becomes clear that CRC's building fits into this upper-market, suburban, elitist area. '[M] egachurches generally are an urban phenomenon located in the suburbs of very large cities' (James 2007:193). Why did they choose to build CRC in the east of Pretoria, in one of the most expensive suburbs and not in Mamelodi or lower income suburbs in Pretoria west? The sheer size and architecture of the building demand attention. Entering the building, one finds a massive, clean foyer. Everything is well maintained and nothing is out of place. The church plays into the notion that pervades our society: 'big is better and stronger' (James 2007:191).

Requesting to speak with someone about the church leads to an interrogation of sorts. The first questions we were asked were the following: 'are you a member of the church?' and 'with whom do you have an appointment?' If you cannot positively answer the first round of questions, it would be more difficult to meet with someone. During the conference visit, we were initially denied just to view the auditorium.

1.For a more in-depth study on megachurches in South Africa, Genevieve James's PhD thesis can be considered.

2.See http://www.silverlakes.co.za/hoa/about-us 
On a follow-up visit, we were again initially denied, only to be reluctantly and partly accommodated in the end.

The auditorium of CRC can seat up to 7000 people. The erection of the church building started in 2012 and was completed in beginning 2014 (Bester 2014:26). During the conference visit, we were informed that the building alone was over R200 million debt free. And it was mentioned: 'Our pastor, he is the man who holds the vision for the church, he does not believe in bank loans, we do not owe anyone!'

Maddox (2012) notes the universal rhetoric of growing megachurches:

A tiny group began in the pastor's lounge room; then borrowed, leased and finally bought a warehouse. Once sufficiently established, they commissioned purpose-built premises, completing the main auditorium, conference facilities, television studio, gymnasium and school, before 'planting' offshoots in nearby cities and foreign lands. (p. 153)

CRC's story fits squarely into the same rhetoric, starting as a small church in 1994 and now having congregations all over South Africa and internationally with over 53000 members. ${ }^{3}$

On a typical Sunday, there are three services at the Pretoria congregation for the CRC. You are struck by the amount of expensive cars that are parked on the premises. Cars are parked outside on the sidewalk as there is not enough parking. There are also about 15 busses parked outside. People are bussed in from various areas of the city.

In the parking area, it might seem for a moment as if the rainbow nation ideals have been realised. People from different races and cultures, old and young, are all gathered here for the same end in mind, namely, to hear the message of the senior pastor, At Boshoff.

CRC is dominated by two senior pastors: At Boshoff and Nyretta Boshoff. Not only at CRC, megachurches 'are often dominated by a single, senior pastor' (Yip \& Ainsworth 2013:508). Megachurch pastors tend to have some sort of celebrity status (cf. Paparazzi pastors 2011; Yip \& Ainsworth 2013). During our visits, many people placed an emphasis on the importance of the senior pastor. To be part of the church, it is of utmost importance to understand his vision and to follow suit. At Boshoff not only represents but also embodies the CRC brand.

Yip and Ainsworth (2013:508) note that in most cases megachurches are made up of 'attendees' rather than 'members'. Church attendees, unlike members, are not involved in:

decision-making about the church's operations, structure or practices. However, church attendees are involved through participation in small 'care groups,' which meet regularly outside the Sunday service and further reinforce the vision and teachings of the senior pastor. (Yip \& Ainsworth 2013:508)

3.See http://www.crc.org.za/
It seems that it is no different at CRC as they state: 'Here we grow and thrive with other believers to discover our potential and purpose through sharing the word received by Ps. At on Sundays' ${ }^{4}$

Entering the building on a Sunday, you are met with contemporary-style modern music. There are doors that are bigger than life and lights everywhere. The lights, music and sound create an effect that is distinctly 'unchurchlike' (Yip \& Ainsworth 2013:510). You can enter the bookshop to your left to buy the senior pastor's books, sermons or the band's music. On your right, you can sit at the coffee shop. Yip and Ainsworth (2013:508) note that the senior pastor of a megachurch, who 'constitutes a human brand', is not only 'transferred to the production of merchandise (music, books, audio recordings) but also used to co-enact the identity of the church'.

Seated in the auditorium, you are bombarded with a $8064 \mathrm{~mm} \times 4608 \mathrm{~mm}$ larger-than-life LED screen (Bester 2014:29), and state-of-the-art speakers with advertisements and ' $T V^{\prime}$ ' presenters who are dressed by boutique stores. They advertise a strong focus on 'The Pastor' and his apparent life-changing sermons that you can buy at the bookshop.

From the moment you drive into the premises, there are redshirted ushers to ensure you park on the right parking space and walk on the right walkway. Everywhere you walk in the building, there is a smiling red-shirted usher to remind you to 'enjoy the service' and herd you in the right direction. They herd you until you are seated, and strongly discourage you to choose your own seat but to be content with the one allocated to you.

Entering the enormous, modern building, it is not immediately clear what you will get in this place: is it a concert hall; is this a night club or rock concert 'minus the scents of sin, smoke and alcohol' (Maddox 2012:147); or can this be a church? It has all the elements of a modern-day building, including live stream capabilities; however, it lacks the traditional Christian symbols that you will find in a traditional Christian church (cf. Yip \& Ainsworth 2013:511).

The rhetoric of 'one church, many locations' is constantly proclaimed. What is meant with this is not one, universal, Catholic Church; what is meant is that CRC is the only church, and this church has many locations. It was made clear to us during the various information sessions that CRC does not work or partner with other (especially small) churches. They choose to bus in people from places far from the church. They are brought in and then sent back to where they came from.

Money is a strong focus of the church. You are reminded to tithe and above that to give abundantly. Our various information sessions informed us that CRC focuses on the rich rather than the poor. Without the rich, the poor cannot be 4.See http://www.crc.org.za/ 
bussed in and out. The church needs more rich people than poor people.

\section{Encounters at Hatherley dumping site, Mamelodi East}

Mamelodi Township is located in the north-eastern outskirts of the city and is part of the City of Tshwane Metropolitan Municipality. It has a rough estimated population of 1 million people (Mamelodi Mesh 2008). ${ }^{5}$ Mamelodi is located in Region Six of the Metropolitan and is divided into western and eastern parts. Mamelodi is one of the biggest townships in the City of Tshwane with an almost $98 \%$ representation of black communities who speak Northern Sotho, Ndebele, Zulu and Tsonga (Nkosi 2014:14). The dumpsite is located in the eastern part with a new Reconstruction and Development Programme development in the vicinity.

Through various forced removals and constant fighting for survival, Mamelodi continues to be a fragmented community. The people of Phomolong, Mamelodi EXT 6 were removed from Marabastad to 'make way for new developments. Twelve years later, the proposed developments never occurred' (cf. Council moves Avondzon squatters to a rubbish dump 2008; De Beer 2014b:222; Funeral for drowned Mamelodi boys 2015; Landman 2010; Marabastad protests relocation 2002; Ndlazi 2016; Selaluke 2012). Hatherley dumpsite serves as a reminder of the fractured, neglected, abused and vulnerable communities of Tshwane. Social boundaries are drawn around communities such as these. This is evident through the lack of interaction from churches at the dumpsite, especially the CRC.

Entering the dumpsite, you will have the feeling that you are on a discarded place, a place outside people's daily thoughts. You know that you are at the periphery where vulnerable and poor people are disconnected from normal social networks. The unidentifiable smells challenge your sense of smell. Hundreds of people, caught in the vicious jaws of poverty, inhabit the dumpsite. They run after the dump trucks, seeking some form of livelihood in other people's garbage. They compete with the heavy machinery to collect potentially valuable items before they are destroyed or buried underneath a mountain of garbage. One person's trash is another's treasure. Here are people who live on the margins of society where their basic human rights and dignity are not affirmed.

People living at Hatherley is not an isolated incident. In his article Jesus in the dumping sites: Doing theology in the overlaps of human and material waste, De Beer (2014a) lists other international dumpsites where people are living and surviving on dumpsites. De Beer (2014a:) notes that these dumpsites give us an insight into what is wrong with society:

5.Sources vary on the population of Mamelodi. According to Statistics South Africa's 2011 Census, Mamelodi has a population of 334577 counted persons. Other sources estimate that this is a conservative figure. Wireless Africa (see http:// sources estimate that this is a conservative figure. Wireless Africa (see http://
wirelessafrica.meraka.org.za/wiki/index.php/Mamelodi_Mesh) estimates the population close to one million.
Dumping sites are prophetic signs of what is wrong with our society - they are places where humans are discarded as waste together with toxic materials, dirty needles and wasted food; and a sign of the grossest possible failure of creation in its most vulnerable state - unsustainable both ecologically and in terms of human well-being. (p. 1)

Nkosi (2014:9) has indicated that the Hatherley dumpsite was established without following international standards for a municipal solid waste management system, as articulated in the National Environmental Management Waste Act 59 of 2008 , hence the dramatic impact on the environment.

Standing amidst the chaos and unidentifiable smells, one is confronted with an uncomfortable feeling, a feeling of uneasiness. How is this injustice possible? How can people be discarded like this? How can government allow this? How is the church of Jesus Christ allowing this to happen? Am I contributing to this injustice in some way?

During the 2015 conference, attendees were introduced to the dumpsite by the site manager. He spoke about the struggles the poor and vulnerable people are faced with on a daily basis, about the babies that are born in this harsh, unhealthy place.

During another visit, ${ }^{6}$ we met with two young men living on the dumpsite. From the garbage, they have constructed a temporary shelter. Cooking (rotten) meat, chicken and other vegetables that they found digging through the garbage, they welcomed us into their world. The following is an attempt to reconstruct our conversation on their life as experienced on the dumpsite:

Q1. Where do you get food from?

A. We get food from the rubbish offloaded by trucks. For instance, we collected this meat that we are now cooking from the rubbish that a truck dumped this afternoon.

Q2. Where do you get water to drink from?

A. We go to ask water outside the dumping site. It is quite far where we get the water from.

Q3. Where do you go to use ablution and toilet facilities?

A. We use the bush because there are no toilet facilities here on site.

Q4. Where did you come from and why did you choose to stay here?

A. I came from Limpopo and decided to live here to get recycling material to sell for money. My brother is from Mozambique but has been here in South Africa for more than 10 years. I do not have an ID book or birth certificate and therefore cannot find a proper job. I have done piece jobs, but you are treated badly and do not always get paid. It is better to be here because I know what to expect. Without my ID I also cannot get medical treatment from the clinic that I require.

Q5. Are you looking for a job?

A. We have skills like plumbing, painting, roofing, electrical work, carpentry and car repairing, but because of lack of identity documents we cannot find a job.

$6 . F o r$ this specific visit, two of the article's authors, Ezekiel Ntakirutimana and Wayne Renkin, visited Hatherley with the objective to engage in conversation with people Renkin, visited Hatherley with the objective to engage in conversation with people
who are living on the dumping site and to try and understand their daily struggles and how they see the role of the church at the dumping site. 
Q6. How many people do you think live here at this dumping site?

A. We believe there are more or less 180, consisting of South Africans and foreign nationals.

Q7. Have you seen any church coming to help people here with food or any other assistance?

A. Not really, we only see individuals bringing food but also not often.

Q8. Do you think churches can help to change the living conditions of people here?

A. We do not think churches are willing to help.

Q9. If the church would come to help, what kind of assistance would you request?

A. Churches can organise meetings with people. They can buy land and give it to people so that they can build and do their own gardening to produce food by themselves.

Q10. What are some of the bigger challenges experienced here on the dumping site?

A. Amongst other, challenges include people coming from outside to sell drugs here which creates insecurity on the site.

Q11. Do you think that you can attend a church in the close vicinity?

A. No. I do not think they will let me come in because of where I stay and what I do.

Q12. How much do you make in selling recycling material?

A. Sometimes we make R80 per day.

These two men are not the only people who choose the dumping site over informal work. For instance, Modipa (2014) reported in a local newspaper how a 30-year-old woman lost her job as a domestic worker. The report reveals also how she made much more money than being a domestic worker or even selling fruits. But it does not come without its own challenges as it is not easy working on the dumping site. Daily Maverick (Health-E News 2015) describes another story of a different kind related to a 20-year-old man who lived on the Hatherley dumpsite, 'sorting through rubbish for recycling by day to make money to score hits of nyaope ${ }^{7}$ by night'. Rekord newspaper reported a story of two young boys, 6 and 11 years old, drowned whilst swimming in dirty water at Hatherley. The news article further reported that the Tshwane Metro 'supported the family through their time of bereavement', but with no mention how further steps were taken to prevent the same problem happening again in the future (Funeral for drowned Mamelodi boys 2015).

\section{A feast with no boundaries and no privileged space (Lk 14:16b-23) 'Hidden' cultural scripts}

There are two main ways to approach the parables when it comes to their interpretation. One can read the parables in

\footnotetext{
7.Nyaope is also known as whoonga or wunga. It is a fine white powder with a cocktail of ingredients. 'The ingredients of nyaope are not always known, and in fact the recipe may vary from place to place' (Solomons \& Moipolai 2014:302). It has been reported that possible ingredients of nyaope include heroin, strychnine/rat poison reported that possible ingredients of nyaope include heroin, strychnine/rat poison,
detergent powder, anti-retroviral drugs (ARVs) and efavirenz (Grelotti et al. detergent powder, anti-retroviral drugs (AR
2014:512; Solomons \& Moipolai 2014:302).
}

their literary contexts, that is, the way in which the parables of Jesus were redactionally applied by the evangelists, or one can interpret the parables in the socio-cultural, political, economic and religious context in which they were told by Jesus (ca 27-30 CE). The reading of the Feast below takes the second approach.

For the second approach, it is important to take serious the cultural scripts (social values) that were part of the world of Jesus. What do we find in a specific parable that is 'hidden' to the modern reader? What social values were part of the repertoire of Jesus and his audience - their shared cultural world of references - that resonance in a parable? (see Scott 2001:109-117). In other words, 'what cultural scripts are embedded in the parable of the Feast that the modern reader should take cognizance of?' What did the hearers of the parable know that the modern reader does not now, the socalled native's point of view? Also, if there are 'hidden' cultural scripts embedded in a parable, how can they be brought to the surface? Social-scientific criticism, as an exegetical approach, consciously addresses these questions by using reading scenarios to identify and interpret social values embedded in ancient stories like the parables. These reading scenarios enable the modern reader to hear (read) the parable as the first hearers did, to value what they valued, and to understand what they understood (Neyrey 1996:115).

What are the social values that are 'hidden' in the parable of the Feast? ${ }^{8}$ Firstly, the social setting of the parable of the Feast, namely, a city, would have evoked certain physical and social aspects that were typical of pre-industrial cities in the time of Jesus. In pre-industrial cities location, social status and location of dwelling went hand in hand. Walls physically demarcated who belonged where, and gates controlled the interaction between the different social groups that inhabited the city. The political and religious elite (those with honour, status, power and privilege) occupied the walled-off centre of the city, and the non-elites occupied the outlying area of the city, located between the inner and outer walls of the city (Rohrbaugh 1991:133-146). Occupation in the outlying area normally was organised in terms of particular families, income groups, guilds, ethnicity and occupation. The elite and non-elite thus were physically and socially isolated from each other. The pre-industrial city also 'housed' the socially ostracised (e.g. prostitutes, beggars, tanners and lepers). These people lived outside the outer walls of the city and were only allowed to enter the city during the day, for example, to look for work as day labourers. The important fact for the understanding of the parable is that social contact between the different groups, especially the elite and the non-elite, was nearly none-existent. ${ }^{9}$

8.For a detailed discussion of the social values embedded in the parable, see Van Eck (2013:7-9).

9.'A member of the urban elite took significant steps to avoid contact with other groups except to obtain goods and services. Such a person would experience groups except to obtain goods and services. Such a person would experience social and geographical distancing, enforced and communicated by interior walls, characterized both internal city relations and those between city and country' (Rohrbaugh 1991:136) 
Secondly, the fact that the feast consisted of a meal immediately would have been understood by the hearers of the parable as a ceremony which included aspects such as boundary making, purity concerns and status. Also, the extension of an invitation would have evoked aspects such as gossip, honour, patronage and reciprocity. In the Mediterranean world (the world of Jesus), shared meals were seen as a ceremony that confirmed shared values, structures, status and honour rating. ${ }^{10}$ Likes, therefore, only ate with likes (persons with the same social standing, status and honour rating). Elite, who occupied the walled-off centre of the city, only ate with other elite within the inner wall, and not with non-elites occupying the outlying area of the city or the impure and marginalised living outside the city walls. Meals also had to do with what is known as reciprocity. Accepting an invitation to a meal was to be followed up by the same kind of invitation to the host. A guest who did not reciprocate by becoming a host to the initial host was seen as someone without any honour, as was someone who ate with persons with a lower honour status.

As a rule of thumb, persons who were invited to a meal normally received two invitations. The first invitation, which informed guests that a feast was going to take place, in essence, was an honour challenge; will the invited guests consider my honour rating and status as such that they would attend, also willing to abide with the reciprocal implications of their acceptance of my invitation? The answer to this question was given implicitly when the second invitation was extended on the day and time of the meal. In the time interval between the first and the second invitations, first-century Mediterraneans normally practised what can be called gossip as a social game. In oral and non-literate societies, such as first-century Palestine, gossip was an institutionalised means of informal communication, interwoven in the daily affairs and interactions between people, and everybody partook in it (Andreassen 1998:41). As a controlled cultural form, gossip had several social functions, such as consensus building, the reaffirmation and enforcement of group values, boundary maintenance and the moral assessment of individuals (Rohrbaugh 1991:251-256). Gossip, and status and honour, thus were two sides of the same coin, 'one of the chief weapons which those who consider themselves higher in status use to put those whom they consider lower in their proper place' (Gluckman 1963:309). ${ }^{11}$

\section{Reading the parable ${ }^{12}$}

The parable of the Feast is a short story by Jesus in which a man prepared a feast and to which he invited many guests.

10. When people gathered for meals in first-century Mediterranean cultures, the event was laden with meaning. Meals were highly stylized occasions that carried significant social coding, identity formation, and meaning making. Participating in a meal entailed entering into a social dynamic that confirmed, challenged, and negotiated both who the group as a whole was and who the individuals within it were' (Taussig 2009:22).

11.For a more extensive description of gossip as a necessary social game in inter alia the first-century Mediterranean world, see Van Eck (2012:2-9).

12.For a detailed reading of the parable, see Van Eck (2013:1-12).
That the man most probably was one of the rich elite can be deducted from the parable; he has the means to entertain many. The double invite in the parable also illustrates the man's wealth, because the double invite was a special sign of courtesy practised by the wealthy (Scott 1989:169). The host most probably was part of the urban elite, who lived in the walled-off centre of the city.

Because only people with the same social standing, status and honour rating ate together, his invited most probably also were from the elite who lived in the walled-off centre of the city. That this was the case is clear from the parable, at least in the case of the first two invitees. The first invitee had the means to acquire a piece of land, and the second has bought five yokes of oxen, indicating that he owned a large estate. Because likes only ate with likes, the other invited guests, like the one who recently got married, most probably were of the same or even higher status as the host.

As stated above, the (first) invitation extended to the guests, in essence, was an honour challenge to the invited. Did the invited consider the host as one of their peers? Was his honour rating high enough for the invited to accept the invitation? Were they willing to reciprocate after accepting the invitation? Would their attendance enhance their respective honour ratings? Or would attendance shame them?

Almost immediately after the first invitation, the gossip network amongst the elite would have kicked in before the second invitation was received. As put by Rohrbaugh:

Initially the potential guest would have to decide if this was a social obligation he could afford to return in kind. Reciprocity in regard to meals was expected.... But more importantly, the time between the invitations would allow opportunity for potential guests to find out what the festive occasion might be, who is coming, and whether all had been done appropriately in arranging the dinner. Only then would the discerning guest be comfortable showing up. The nearly complete social stratification of pre-industrial cities required keeping social contacts across class lines to a minimum and elaborate networks of informal communication monitored such contacts to enforce rigidly the social code. (Rohrbaugh 1991:141; emphasis added)

When the second invitation is extended, it is clear that the host's honour challenge is turned down. This is clear from the three excuses in Luke 14:18-20. Important here is not the content of the excuses, but what lies behind it. The host is shunned, not only by the three guests who make excuses but by all of the invited. Everybody who was invited (the many) turns down the invitation. Nobody shows up because of the gossip network of the community. The host was morally assessed, and boundary maintenance took place. Something was wrong with the feast. What it was, the parable does not say. It was, however, a good enough reason not to attend.

Receiving this news, the host got angry. He did not make it amongst his peers. Boundaries were drawn and he was rejected and shamed. What could he do to save face? This is 
the surprising element of the parable. The host decides to be a different kind of host, a host not interested in honourratings or balanced reciprocity (what he can get out of inviting people to a feast). He, therefore, sends his slave to invite people living in the wider streets and squares and the narrow streets and alleys (Lk. 14:21) - those who live in the city between the inner and outer walls. And when there is still room for more, he sends his slave to invite those in the roads and country lanes or hedges (Lk. 14:23) - the socially impure (expendables) living outside the city walls.

Whilst the urban elite first invited took significant steps to avoid contact with those living outside the inner and outer walls of the city, the host socialises and eats with them. He abandons the ever-present competition for acquired honour in the first-century Mediterranean world, replaces balanced reciprocity (quid pro quo) with generalised reciprocity (giving without expecting anything back) and declares the purity system which deems some as socially and ritually (culturally) impure null and void. All walls have been broken down, privileged space was erased and the world was upside down.

Not, however, from the perspective of the kingdom of God, the point Jesus wanted to make with the parable. In the kingdom, elite hosts are real hosts when they act like the host in the parable: giving to those who cannot give back, breaking down physical (walls) and man-made boundaries (purity and pollution) and treating everybody as family (generalised reciprocity), without being afraid of being shamed. This was the kingdom of God, a kingdom in which the pivotal value of honour that organised and stratified society had no role, a kingdom in which purity did not ostracise and marginalise the so-called unclean or expendables. In the kingdom, there are no boundaries between people, and no space is deemed as privileged.

\section{Conclusion}

The physical design of the pre-industrial city is the determinant of social status. People were separated by walls; political and social elites were walled off, and gates controlled the interaction between the different social groups that inhabited the city. The socially ostracised were 'housed' outside the walls and were only allowed to enter during the day for very specific purposes such as working as day labourers.

Not much has changed in the post-apartheid city. Today the inner city no longer hosts all of the elite, as the elite have moved to the periphery of the city and created new walledoff, privileged spaces. If you are not part of the elite, you may not freely enter the new walled-off places. Entry is limited to invitation and permission. The CRC contributes to the creation of walls and privileged spaces. Physical and metaphorical walls are created. People from Mamelodi and other places that fall outside the social class of the elite are welcome to enter the church, but only when they are invited, given permission and only during certain times. They are bussed in and out again to limit contact between the elite and the non-elite as in the pre-industrial city.

People who are invited to the walled-off CRC are people who can reciprocate. They are not just encouraged, but reminded that they are obliged to give money abundantly to church; otherwise, God will not bless them. You must be able to take part in the quid pro quo system.

In this parable, Jesus is inviting us to be like the host. We must breakdown walls and barriers that uphold the status quo of society, where the vulnerable are ostracised to the margins, to live out a life on a dumpsite, digging through the trash, eating rotten food - all for the sake of survival.

In the church, Christ is the host who invites those on the other side of the wall, those whom society does not welcome. We as the church are challenged by this parable to critically ask the question: Who do we invite and allow to come to the table of Christ? Is there any person that we are excluding? Are we creating boundaries and privileged spaces on the basis of people's social-economic status? Or are we actively working against the injustice of boundaries? How do we justify spending millions on an exclusive worshipping space whilst there are people in walking distance who are living on a landfill site?

When Jesus and his disciples left the Hulene dump and came out in the beautiful city with all its cars, He stopped and told his disciples that those who they just met at the dump will inherit the kingdom of God. (De Beer 2014a:1, quoting Father Juliao Mutemba on his reflection on the Hulene Dumpsite in Maputo, Mozambique)

\section{Acknowledgements Competing interests}

The authors declare that they have no financial or personal relationships which may have inappropriately influenced them in writing this article.

\section{Authors' contributions}

All authors made an equal contribution to the writing of the article.

\section{References}

Andreassen, R., 1998, 'Gossip in Henningsvær', Etnofoor 11, 41-56.

Bester, G., 2014. 'Christian Revival Church', Pro-Systems: Africa News, pp. 26-29, May/ June Edition.

'Council moves Avondzon squatters to a rubbish dump', 2008, The Bronberger, 11 November, viewed from http://www.bronberger.co.za/index.php?option=com content\&view=article\&id=295: council-moves-avondzon-squatters-to-a-rubbishcontent $\&$ view $=$ article\&id $=295:$ coun
dump\&catid $=55$ :aktueel $\&$ Itemid $=70$

De Beer, S., 2014a, 'Jesus in the dumping sites: Doing theology in the overlaps of human and material waste', HTS Teologiese Studies/Theological Studies 70, 1-8. $\mathrm{http}: / / \mathrm{dx}$.doi.org/10.4102/hts.v70i3.2724

De Beer, S., 2014b, 'Whose knowledges shape our city? Advancing a communitybased urban praxis', De Jure 47, 218-230.

'Funeral for drowned Mamelodi boys', 2015, Rekort Pretoria East, 17 January, viewed from http://rekordeast.co.za/39309/funeral-drowned-mamelodi-boys/

Gluckman, M., 1963, 'Gossip and scandal', Current Anthropology 4, 307-316. http:// dx.doi.org/10.1086/200378 
Grelotti, D.J., Closson, E.F., Smit, J.A., Mabude, Z., Matthews, L.T., Safren, S.A. et al., 2014, 'Whoonga: Potential recreational use of HIV antiretroviral medication in South Africa', AIDS and Behavior 18, 511-518. http://dx.doi.org/10.1007/s10461013-0575-0

Harvey, D., 2012, Rebel cities: From theright to the city to the urban revolution, Verso, London.

Health-E News, 2015, 'Why is SA not offering painless withdrawal to drug addicts?', Daily Maverick, 17 August, viewed from http://www.dailymaverick.co.za/ article/2015-08-17-health-e-news-why-is-sa-not-offering-painless-withdrawal-todrug-addicts\#.VwsnFpx96W8

James, G.J., 2007, 'And God said "Let there be Charismatics in the City": A study into the practise and presence of a Charismatic Megachurch in the City of Durban' $\mathrm{PhD}$ thesis, University of Kwazulu-Nata

Landman, N., 2010, 'Babies dumped at birth in Pretoria', Times Live, 15 March, viewed from http://www.timeslive.co.za/local/2010/03/15/babies-dumped-at-birth-inpretoria

Maddox, M., 2012, "'In the Goofy parking lot": Growth churches as a novel religious form for late capitalism', Social Compass 59, 146-158. http://dx.doi.org/10.1177/ 0037768612440954

Mamelodi Mesh, 2008, Wireless Africa, wiki, viewed from http://wirelessafrica. meraka.org.za/wiki/index.php/Mamelodi_Mesh

'Marabastad protests relocation', 2002, SAPA, viewed from http://www.news24.com/ xArchive/Archive/Marabastad-protests-relocation-20020811

Modipa, D., 2014, 'This job's not for sissies!', Daily Sun, 9 September, viewed from http://m24arg02.naspers.com/argief/berigte/dailysun/2014/09/09/4/SUNXTRADAY 31 0_573911256.htm

Ndlazi, S., 2016, 'Land Grab Chaos', Pretoria News, 17 April, p. 1.

Neyrey, J.H., 1996, 'John 18-19: Honor and shame in the passion narrative', Semeia 68, 113-137.

Nkosi, L., 2014, 'An evaluation of the municipal solid waste management system within city of Tshwane Metropolitan Municipality in Mamelodi East Township, Gauteng province, South Africa', Master's thesis, University of Pretoria, Pretoria.
'Paparazzi pastors', 2011, City Press, 16 April, viewed from http://www.news24.com/ Archives/City-Press/Paparazzi-pastors-20150429

Rohrbaugh, R.L., 1991, 'The pre-industrial city in Luke-Acts: Urban social relations', in J.H. Neyrey (ed.), The social world of Luke-Acts: Models for interpretation, pp. 125-149, Hendrickson Publishers, Peabody, MA.

Scott, B.B., 1989, Hear then the parable: A commentary on the parables of Jesus, Fortress Press, Minneapolis, MN.

Scott, B.B., 2001, Re-imagine the world: An introduction to the parables of Jesus, Polebridge Press, Santa Rosa, CA

Selaluke, S., 2012, 'Mamelodi under water', Rekort Pretoria East, 20 August, viewed from http://www.looklocal.co.za/looklocal/content/en/pretoria-east/pretoriaeast-news-general?oid=6044449\&sn=Detail $\&$ pid=4980311\&Mamelodi-under water

Soja, E.W., 1971, 'The political organization of space', Association of American Geographers: Resource Paper 8, 1-54. http://dx.doi.org/52591

Solomons, Y. \& Moipolai, P., 2014, 'Substance abuse: Case management and dental treatment', South African Dental Journal 69, 298-315.

Statistics South Africa, 2011, Census data.

Taussig, H., 2009, In the beginning was the meal: Social experimentation and early Christian identity, Fortress Press, Minneapolis, MN.

Van Eck, E., 2012, 'Invitations and excuses that are not invitations and excuses: Gossip in Luke 14:18-20', HTS Teologiese Studies/Theological Studies 68(1), Art. \#1243, 10 pages. http://dx.doi.org/10.4102/hts.v68i1.1243

Van Eck, E., 2013, 'When patrons are patrons: A social-scientific and realistic reading of the parable of the Feast (Lk 14:16b-23)', HTS Teologiese Studies/Theological Studies 69, 1-14. http://dx.doi.org/10.4102/hts.v69i1.1375

Yip, J. \& Ainsworth, S., 2013, “'We aim to provide excellent service to everyone who comes to church!": Marketing mega-churches in Singapore', Social Compass 60, 503-516. http://dx.doi.org/10.1177/0037768613502765 